P. P. Dendy, to investigate the effects of irradiation with a microbeam of ultra-violet light on the protein metabolism of cells, at the Department of Radiotherapeutics, University of Cambridge; D. Gompertz, to investigate the effect of pituitary growth hormone on fat synthesis, at the Department of Biochemistry, University College, London; M. R. Lee, to investigate the control of the generation of vasoactive polypeptides in the blood, at the Department of the Regius professor of medicine, the Radcliffe Infirmary, Oxford; Dr. G. F. Rowland, to investigate nucleic acid synthesis in the isolated pre-cancerous nucleus, at the Department of Chemical Pathology, University College Hospital Medical School, London; Dr. Sheila M. Day, to investigate the factors that influence the binding of amines in normal and neoplastic mast cells, at the Department of Pharmacology, Royal College of Surgeons of England, London; E. A. Newsholme, to investigate the importance of the 6-phosphofructokinase reaction in the regulation of muscle glycolysis, at the Department of Biochemistry, University of Oxford; J. S. Wigglesworth, to investigate the eytology of the human placenta in normal and abnormal pregnancy, at the Department of Morbid Anatomy, University College Hospital Medical School, London.

\section{The Royal Institution: Open Days}

Open days at the Royal Institution are being arranged this year for June 14-15. To mark the centenary of the birth of Sir William Henry Bragg (1862-1942), who was director of the Davy Faraday Research Laboratory from 1926 until 1942, X-ray crystallographic laboratories in Britain are providing a series of exhibits which illustrate the historical development of the subject. The main emphasis of the research work at present proceeding in the Davy Faraday Laboratory is on the application of X-ray diffraction methods to the study of biological mole. cules, and a number of rooms in the Laboratory, where some of the latest work in this field can be seen, will be open to visitors. The exhibition will be open each day from 10 a.m. to 1.0 p.m. and from 2.30 p.m. to 6.0 p.m. Further information can be obtained from the Royal Institution, 21 Albemarle Street, London, W.1.

\section{Course on Aerial Photogrammetry}

A THEORETICAL and technical course on "Aerial Photogrammetry", arranged by the French National School for Geographic Sciences, will be held at Saint. Mandé, near Paris, during June 18-July 27. The programme of lectures will include: general problems of aerial photogrammetry; problems concerning aerial surveys; principles, construction and adjustment of plotting machines; problems concerning mean scales $(1 / 5,000$ to $1 / 50,000)$ and small scales $(1 / 100,000$ and $1 / 200,000)$ plotting; practice of aerial triangulation; mechanical and electronical methods for compensation of blocks in aerial triangulation. There will also be practical instruction on the use of instruments and visits to different places concerned with photogrammetrical activities. Further information can be obtained from the Director, l'Ecole Nationale des Sciences Géograph. iques, 2 Avenue Pasteur, Saint-Mandé (Seine).

\section{Conferences on Dermatoglyphics}

ON the occasion of the Second International Con. ference on Human Genetics, held in Rome during September 6-12, 1961, an organization devoted to research on finger-prints, palms and soles (dermatoglyphics) was formed. Its principal objectives are to promote activity in this field, to distribute information on current investigations, to standardize methods and to hold meetings for the presentation of reports and discussions. Interested workers are invited to communicate with any member of the Organizing Committee: President, Prof. Harold Cummins, Tulane School of Medicine, 1430 Tulane Avenue, New Orleans 12, Louisiana; Chairman, Dr. José Pons, Universidad de Barcelona, Barcelona; Secretary, Mr. Abhimanyu Sharma, 40/C Hanuman Lane, New Delhi-I; Dr. Mariassa Bat-Miriam, Israeli Institute for Biological Research, P.O.B. 19, Ness Ziona; Dr. Sarah B. Holt, University College, Gower Street, London, W.C.1; Commissioner C. H. Vogelius Andersen, Danish Identification Bureau, Politigaardon, Copenhagen V; Dr. Margaret Weninger, Universität Wien, Van Swietengasse 1, Wien IX; Prof. Masaya Yasunaka, Nagasaki University School of Medicine, 1699 Sakomoto-machi, Nagasaki-City.

\section{Announcements}

UNDER the Statute of the Royal Society which provides for the election of persons who either have rendered conspicuous service to the cause of science or are such that their election would be of signal benefit to the Society, the Right Hon. Harold Macmillan has been elected a Fellow of the Royal Society.

CONSEQUENT on the acquisition of the shares of J. W. Towers and Co., Ltd., by A. Gallenkamp and Co., Ltd., the name of J. W. Towers and Co., Ltd., has now been changed to A. Gallenkamp and Co. (Northern), Ltd. The two companies will in future both trade under the registered business name of 'Gallenkamp. (Reg. trade mark)'.

The British Cast Iron Research Association is holding open days during July 3-4. Visitors will be able to see the Association's new laboratory, which is to be inaugurated by the Marquess of Exeter on July 3, and a representative selection of the Association's work will be on show. Further information can be obtained from the Publications Officer, British Cast Iron Research Association, Bordesley Hall, Alvechurch, Birmingham.

A SYMPOsrum on "Sonar Systems", sponsored jointly by the British Institution of Radio Engineers, the Institute of Physics and the Physical Society and the Electrical Engineering Department of the University of Birmingham, will be held in the University of Birmingham during July 9-12. Subjects under discussion will include: propagation; survey equipment; sonar for fisheries; arrays and signal processing. Further information can be obtained from the British Institution of Radio Engineers, 9 Bedford Square, London, W.C.I.

The annual meeting of holders of Nobel Prizes will be held in Lindau during June 24-29. This year the lectures will be given by physicists, among whom will be: Prof. N. Bohr (Copenhagen); Prof. H. C. Urey (California); Prof. R. Hofstadter (California); Prof. J. Franck (North Carolina); Sir John Cockcroft (Harwell); Sir Edward Appleton (Edinburgh); Dr. J. Bardeen (Illinois); Prof. M. Born (Bad Pyrmont); Prof. W. H. Brattain (New Jersey); Prof. W. Heisenberg (Munich). Further information can be obtained from Hans Kiderlen, Nonnenhorn/Bodensee, Uferstrasse $65 a$. 